\title{
PENGEMBANGAN MODUL FISIKA SMA/MA KELAS X BERBASIS INKUIRI TERBIMBING PADA MATERI LISTRIK DINAMIS UNTUK MENINGKATKAN KEMAMPUAN BERPIKIR KRITIS SISWA
}

\author{
Novi Dwi Ariani ${ }^{1}$, Mohammad Masykuri ${ }^{2}$, Suparmi $^{3}$ \\ ${ }^{1}$ Magister Pendidikan Sains, Fakultas Keguruan dan Ilmu Pendidikan, Universitas Sebelas Maret \\ Surakarta, 57126, Indonesia \\ novidwiariani@student.uns.ac.id \\ ${ }^{2}$ Magister Pendidikan Sains, Fakultas Keguruan dan Ilmu Pendidikan, Universitas Sebelas Maret \\ Surakarta, 57126, Indonesia \\ mmasykuri@staff.uns.ac.id \\ ${ }^{3}$ Magister Pendidikan Sains, Fakultas Keguruan dan Ilmu Pendidikan, Universitas Sebelas Maret \\ Surakarta, 57126, Indonesia \\ soeparmi@staff.uns.ac.id
}

\begin{abstract}
Abstrak
Permasalahan dalam penelitian ini yaitu belum digunakannya pembelajaran fisika berbasis inkuiri terbimbing untuk meningkatkan kemampuan berpikir kritis siswa. Penelitian ini bertujuan untuk: 1) mengetahui karakteristik penyusunan modul fisika SMA/MA kelas X berbasis inkuiri terbimbing pada materi listrik dinamis, 2) mengetahui kelayakan modul fisika SMA/MA kelas $X$ berbasis inkuiri terbimbing pada materi listrik dinamis untuk meningkatkan kemampuan berpikir kritis siswa, 3) mengetahui efektivitas modul fisika SMA/MA kelas X berbasis inkuiri terbimbing pada materi listrik dinamis untuk meningkatkan kemampuan berpikir kritis siswa. Jenis penelitian merupakan penelitian pengembangan (research and development) yang menggunakan model 4$\mathrm{D}$ (define, design, develop and disseminate). Analisis data yang digunakan pada tahap define adalah analisis data deskriptif dari hasil wawancara dan analisis kebutuhan, pada tahap design dengan analisis SK dan KD yang digunakan sekolah, pada tahap develop untuk data hasil validasi modul dan data respon siswa dianalisis dengan menggunakan nilai cut off yang dikonversi menjadi kategori kualitas dengan pedoman skor skala 5, data kemampuan berpikir kritis siswa dihitung dengan $n$-gain dan pada tahap disseminate menggunakan nilai cut off yang dikonversi menjadi kategori kualitas dengan pedoman skor skala 5. Hasil penelitian menunjukkan bahwa: 1) karakteristik modul fisika SMA kelas $X$ yaitu: self instructional, self contained, stand alone, adaptive, user friendly yang dikembangkan dengan berbasis inkuiri terbimbing pada materi listrik dinamis dan diintegrasikan dengan kemampuan berpikir kritis pada setiap tahapnya; 2) kelayakan modul fisika SMA kelas X berbasis inkuiri terbimbing pada materi listrik dinamis oleh ahli materi, media, bahasa, dan teman sejawat diperoleh nilai rata-rata persentase sebesar $81,27 \%$ lebih besar dari nilai cut off yaitu $81,17 \%$ sehingga modul dapat dikategorikan "layak"; 3) efektivitas modul fisika SMA kelas X berbasis inkuiri terbimbing pada materi listrik dinamis efektif untuk meningkatkan kemampuan berpikir kritis siswa didapat dari perhitungan $n$-gain hasil belajar siswa dengan nilai 0,47 dalam kategori "sedang" dan ditunjukkan dengan hasil belajar siswa yang memenuhi kriteria ketuntasan minimum (KKM).
\end{abstract}

Kata kunci: Modul, Inkuiri Terbimbing, Kemampuan Berpikir Kritis.

\section{Pendahuluan}

Data hasil Ujian Nasional (UN) tahun pelajaran 2013/2014 menunjukkan presentase daya serap siswa SMA/MA untuk materi listrik statis dan listrik dinamis di Kota Yogyakarta menunjukkan nilai yang paling rendah yaitu
48,66\%. Daya serap untuk materi listrik statis dan dinamis ditingkat provinsi paling rendah yaitu 40,93\%, dan di tingkat nasional 54,80\% di atas satu tingkat dari materi kemagnetan dan elektromagnetik.

Hasil observasi di SMA PIRI 1 menunjukkan pembelajaran fisika belum 
dilaksanakan secara maksimal. Ditemukan keterbatasan antara lain bahan ajar yang belum sesuai dengan siswa. Siswa belum semuanya memiliki bahan ajar karena keterbatasan sekolah dalam penyediaan bahan ajar. Siswa belum memiliki bahan ajar yang berorientasi pada inkuiri terbimbing. Siswa masih kurang termotivasi dalam mengerjakan latihan soal. Selain itu, sarana dan prasarana yang dimiliki sekolah belum digunakan secara maksimal yang disebabkan oleh kurangnya perawatan dan keterbatasan waktu mata pelajaran.

Prastowo (2014) mengemukakan bahwa hal lain yang dapat mempengaruhi motivasi belajar siswa yaitu adanya bahan ajar yang inovatif, karena bahan ajar merupakan segala bahan (baik informasi, alat, maupun teks) yang disusun secara sistematis, yang menampilkan sosok utuh dari kompetensi yang akan dikuasai siswa. Bahan ajar juga digunakan dalam proses pembelajaran dengan tujuan perencanaan dan penelaahan implementasi pembelajaran, misalnya: buku pelajaran, modul, handout, LKS, model atau maket, bahan ajar audio, bahan ajar interaktif, dan sebagainya.

Jacqueline dan Martin Brooks dalam Santrock (2008) menyesalkan karena hanya sedikit sekolah yang benar-benar mengajarkan murid untuk berpikir secara kritis. Sekolahsekolah menghabiskan terlalu banyak waktu untuk membuat murid memberikan jawaban tunggal yang benar dalam cara imitatif daripada mendorong murid untuk mengembangkan pemikirannya, dengan memberikan ide-ide baru dan memikirkan kembali kesimpulan awal. Mereka percaya bahwa terlalu sering guru meminta murid untuk mengulangi, mendefinisikan, mendeskripsikan, menyatakan, dan menuliskan daripada untuk menganalisis, menyimpulkan, menghubungkan, mengumpulkan, mengkritik, menciptakan, mengevaluasi, berpikir, dan berpikir ulang.

Melalui modul inkuiri terbimbing yang digunakan dalam pembelajaran, siswa dilatih untuk mampu mengaitkan informasi pendukung dengan konsep sehingga siswa mampu menemukan dan menyelesaikan permasalahan yang terdapat dalam fenomena terkait. Sugiyanto (2013) mengemukakan bahwa perlu adanya penyusunan modul berbasis inkuiri menggunakan kalimat yang mampu membuat siswa aktif dalam proses penemuan konsep pada saat pembelajaran. Hal tersebut didukung pula dengan penelitian White (1999) yang menyimpulkan bahwa dengan inkuiri pembelajaran dapat menjadi efektif karena siswa terlibat secara langsung dalam penemuan suatu konsep.

Tujuan penelitian pengembangan ini adalah untuk: 1) mengetahui karakteristik penyusunan modul fisika SMA/MA kelas $\mathrm{X}$ berbasis inkuiri terbimbing pada materi listrik dinamis, 2) mengetahui kelayakan modul fisika SMA/MA kelas $\mathrm{X}$ berbasis inkuiri terbimbing pada materi listrik dinamis untuk meningkatkan kemampuan berpikir kritis siswa, 3) mengetahui efektivitas modul fisika SMA/MA kelas $\mathrm{X}$ berbasis inkuiri terbimbing pada materi listrik dinamis untuk meningkatkan kemampuan berpikir kritis siswa.

\section{Metode Penelitian}

Penelitian ini menggunakan metode penelitian dan pengembangan (research and development). Model penelitian dan pengembangan yang digunakan merupakan adaptasi model 4-D (define, design, develop and disseminate) yang dikemukakan oleh Thiagarajan. Produk yang dihasilkan dalam model penelitian dan pengembangan ini berupa modul fisika SMA kelas $\mathrm{X}$ berbasis inkuiri terbimbing pada materi listrik diamis untuk meningkatkan kemampuan berpikir kritis siswa.

Desain eksperimen yang digunakan adalah one group pretest-posttest design. Subjek penelitian diberi pretest terlebih dahulu sebelum diadakan perlakuan menggunakan modul inkuiri terbimbing dan diberi posttest setelah perlakuan.

Subyek uji coba pada penelitian dan pengembangan ini adalah satu validator materi, satu validator media, satu validator bahasa, tiga validator praktisi pendidikan (guru fisika SMA dan teman sejawat), 9 siswa dalam uji coba kecil, dan 20 siswa SMA dalam uji coba kelas besar. Subyek penelitian pada tahap 
penyebaran melibatkan empat guru yang mengajar mata pelajaran fisika SMA kelas $\mathrm{X}$ di Kota Yogyakarta.

Data yang diperoleh pada penelitian dan pengembangan modul pembelajaran fisika berbasis inkuiri terbimbing pada materi listrik dinamis untuk meningkatkan kemampuan berpikir kritis berupa hasil wawancara, data angket kebutuhan siswa dan guru, data hasil validasi ahli (materi, media, dan bahasa), praktisi pendidikan (guru fisika dan teman sejawat), angket keterterapan modul, nilai pretest dan posttest, angket respon serta angket diseminasi produk.

Instrumen pengumpulan data pada penelitian ini menggunakan pedoman wawancara, angket, dan soal tes. Angket yang digunakan adalah: 1) angket analisis kebutuhan siswa dan angket analisis kebutuhan guru; 2) angket validasi modul oleh ahli materi, ahli media, ahli bahasa, dan praktisi pendidikan; 3) angket keterterapan modul; 4) angket diseminasi produk. Soal test terdiri dari soal pretest dan soal posttest yang diintegrasikan dengan indikator berpikir kritis.

Analisis data pada penelitian pengembangan ini bertujuan untuk menjawab rumusan masalah dalam kesimpulan. Teknik analisis data yang digunakan adalah analisis deskriptif kualitatif dan kuantitatif. Analisis data yang digunakan pada tahap define adalah analisis data deskriptif dari hasil wawancara dan analisis kebutuhan, pada tahap design dengan analisis Standar Kompetensi (SK) dan Kompetensi Dasar (KD) yang digunakan sekolah, pada tahap develop untuk data hasil validasi modul dengan pedoman skor skala 5 dan data respon siswa dianalisis dengan menggunakan cut off score (skor atas bawah) (Winnie, 2009). Data kemampuan berpikir kritis siswa dianalisis menggunakan n-gain berdasarkan hasil pretest dan posttest serta pada tahap disseminate dengan pedoman skor skala 5 yang dianalisis menggunakan nilai $c u t$ off.

\section{Hasil Penelitian dan Pembahasan}

\section{Deskripsi Hasil Penelitian}

Penelitian dan pengembangan ini menghasilkan produk berupa modul fisika berbasis inkuiri terbimbing untuk siswa SMA kelas X pada materi Listrik Dinamis. Hasil penelitian dalam setiap tahap yaitu:

\section{a. Pendefinisian}

Tahap analisis kurikulum merupakan tahap untuk mengetahui kurikulum dan kompetensi yang digunakan dan dilaksanakan di SMA PIRI 1. Kompetensi yang digunakan pada penelitian dan pengembangan bahan ajar berdasarkan kurikulum KTSP dengan standar kompetensi yaitu menerapkan konsep kelistrikan dalam berbagai penyelesaian masalah dan berbagai produk teknologi serta kompetensi dasar yang terdiri dari: 5.3 menggunakan alat ukur listrik, 5.1 memformulasikan besaran-besaran listrik rangkaian tertutup sederhana (satu loop), 5.2 mengidentifikasi penerapan listrik AC dan DC dalam kehidupan sehari-hari.

Hasil wawancara dan pengisian angket digunakan untuk menganalisis kebutuhan guru dan siswa pada SMA PIRI 1. Berdasarkan hasil wawancara dan pengisian angket menunjukkan bahwa siswa memiliki motivasi belajar rendah dikarenakan kurang tertarik untuk mengerjakan latihan soal. Siswa cenderung untuk menghafal persamaan dan kurang memahaminya, sehingga terdapat kesulitan ketika menerapkan persamaan tersebut pada persoalan.

Siswa pasif dalam kegiatan pembelajaran di kelas dikarenakan guru lebih banyak menggunakan metode ceramah, sehingga pembelajaran di kelas terkesan searah. Siswa perlu dilibatkan dalam penemuan pengertian yang ingin diketahuinya, sehingga dalam pembelajaran siswa dapat lebih aktif dengan menemukan konsep sendiri melalui merumuskan prosedur, menganalisis hasil dan mengambil kesimpulan secara mandiri dengan arahan dan bimbingan guru. Oleh karena itu dalam pembelajaran diperlukan modul fisika berbasis inkuiri terbimbing untuk meningkatkan kemampuan berpikir kritis siswa. Kindatter, Wilen, \& Ishler dalam Suparno (2013) menyatakan bahwa inkuiri sebagai model pengajaran dimana guru melibatkan kemampuan berpikir kritis siswa 
untuk menganalisis dan memecahkan persoalan secara sistematik.

\section{b. Perancangan}

Produk yang dihasilkan berupa draf awal modul fisika SMA/MA kelas $\mathrm{X}$ berbasis inkuiri terbimbing pada listrik dinamis untuk meningkatkan kemampuan berpikir kritis siswa. Modul disusun sebagai bahan ajar siswa secara mandiri, sehingga siswa mampu membelajarkan diri-sendiri. Modul terdiri dari satu unit kompetensi dan sub kompetensi yang terdapat dalam satu modul secara utuh serta dilengkapi dengan ikon-ikon yang membantu siswa dalam penemuan konsep sesuai langkahlangkah inkuiri terbimbing.

Penyusunan awal draf modul akan dihasilkan: 1) cover (berisi judul modul menggambarkan materi yang akan dipelajari di dalam modul); 2) bagian pendahuluan (latar belakang, standar kompetensi dan kompetensi dasar yang digunakan, indikator pembelajaran, petunjuk penggunaan modul, peta isi modul, dan peta konsep); 3) bagian isi (bagian isi terdiri dari kegiatan siswa 1, kegiatan siswa 2, dan kegiatan siswa 3) dan setiap kegiatan siswa meliputi standar kompetensi, kompetensi dasar, gambar terkait, fenomena terkait, kegiatan diskusi, kegiatan pengumpulan data percobaan, uraian materi, latihan soal; 4) bagian penutup (soal evaluasi, kunci jawaban, daftar pustaka, dan glosarium).

\section{c. Pengembangan}

Pembuatan draf awal modul yang telah mencapai $75 \%$ merupakan produk yang siap untuk disunting. Produk melewati tahap penyuntingan yang dilakukan oleh dosen pembimbing. Produk tersebut dikonsultasikan kepada dosen pembimbing untuk mendapatkan saran dan masukan yang digunakan sebagai revisi. Saran dan masukan dosen pembimbing dapat dilihat pada Tabel 2.

Tabel 1 Saran dan Masukan dosen pembimbing terhadap draf awal modul

\begin{tabular}{ll}
\hline \multicolumn{1}{c}{ Saran } & \multicolumn{1}{c}{ Perbaikan } \\
\hline $\begin{array}{l}\text { Sampul dihilangkan tanda } \\
\text { lingkarannya }\end{array}$ & Sudah dihilangkan \\
\hline $\begin{array}{l}\text { Rumusan masalah jika dihendaki } \\
\text { jawaban lebih dari satu, baiknya } \\
\text { diberi keterangan atau poin a, b, c }\end{array}$ & $\begin{array}{l}\text { Penambahan (Boleh } \\
\text { menjawab lebih dari 1) } \\
\text { setelah pertanyaan }\end{array}$ \\
\hline $\begin{array}{l}\text { Kata pengantar hendaknya diberi } \\
\text { pengertian inkuiri terbimbing }\end{array}$ & Telah disisipkan \\
\hline Pemberikan kata "halaman" di atas & Telah dilengkapi \\
\hline
\end{tabular}

\begin{tabular}{ll}
\hline \multicolumn{1}{c}{ Saran } & \multicolumn{1}{c}{ Perbaikan } \\
\hline nomor daftar isi & \\
\hline $\begin{array}{l}\text { Keterangan pada alur peta konsep } \\
\text { harus ada }\end{array}$ & $\begin{array}{l}\text { Telah diberikan } \\
\text { keterangan }\end{array}$ \\
\hline $\begin{array}{l}\text { Kegiatan eksperimen, hendaknya } \\
\text { dilengkapi keterangan alat dan } \\
\text { bahan yang disediakan }\end{array}$ & $\begin{array}{l}\text { Telah diberikan daftar } \\
\text { alat dan bahan yang } \\
\text { disediakan }\end{array}$ \\
\hline Peta konsep, lihat hyperphysics & Telah direvisi \\
\hline $\begin{array}{l}\text { Gambar pembacaan multimeter } \\
\text { pada halaman 20 diperjelas dan } \\
\text { diperbesar }\end{array}$ & $\begin{array}{l}\text { telah diganti yang } \\
\text { lebih jelas dengan } \\
\text { pengambilan foto }\end{array}$ \\
\hline $\begin{array}{l}\text { Gambar Fenomena 2, diganti } \\
\text { dengan barang-barang elektronik }\end{array}$ & Telah diganti \\
seperti TV, setrika, dan sejenisnya & \\
\hline $\begin{array}{l}\text { Fenomena 3, hendaknya } \\
\text { ditambahkan gambar bola lampu } \\
\text { dari hasil dokumentasi pribadi }\end{array}$ & Telah ditambah \\
\hline
\end{tabular}

Tahap selanjutnya adalah validasi modul sebelum diujicobakan. Validitas diuji oleh tiga orang ahli, yaitu ahli materi, media, dan bahasa yang mengacu kepada kisi-kisi dan komponen subjek validasi. Data uji validitas modul fisika berbasis inkuiri terbimbing pada materi listrik dinamis disajikan pada Tabel 2.

Tabel 2 Hasil Analisis Validasi Modul

\begin{tabular}{lll}
\hline & \multicolumn{1}{c}{ Validator } & Kategori \\
\hline Ahli materi & 89,00 & Baik \\
Ahli media & 135,00 & Baik \\
Ahli bahasa & 16,00 & Baik \\
Praktisi pendidikan & 140,00 & Baik \\
\hline
\end{tabular}

Berdasarkan Tabel 2 diketahui bahwa hasil validator ahli materi memiliki jumlah skor 89 dari rentang skor 22 sampai 110 dengan kategori "baik", validator ahli media memiliki jumlah skor 135 dari rentang nilai 33 sampai 165 dengan kategori "baik",, validator bahasa dengan skor 16 dari rentang skor 4 sampai 24 kategori "baik",, dan validator praktisi pendidikan (dua guru fisika dan dua teman sejawat) memiliki rata-rata jumlah skor 140 dari rentang skor 34 sampai 170 dengan kategori "baik",. Sehingga dapat disimpulkan bahwa modul fisika SMA kelas X pada materi listrik dinamis untuk meningkatkan kemampuan berpikir kritis termasuk dalam kategori "baik" untuk digunakan.

Uji kelayakan modul dianalisis dengan menggunakan hasil validasi oleh ahli materi, ahli media, ahli bahasa dan praktisi pendidikan. Jika skor rata-rata hasil penilaian lebih dari cut off score (skor atas bawah), maka dapat disimpulkan bahwa modul layak untuk digunakan. Hasil penilaian dari validator menunjukkan nilai rata-rata presentase 
keidealan lebih dari nilai cut off score yaitu $81,27>81,17$, maka dapat disimpulkan modul fisika SMA/MA kelas $\mathrm{X}$ berbasis inkuiri terbimbing termasuk dalam kriteria "layak" digunakan dalam pembelajaran. Hasil perbaikan modul berdasarkan saran dan masukan dari validator disajikan pada Tabel 3 .

Tabel 3 Saran dan Masukan Validator

\begin{tabular}{|c|c|c|}
\hline Validator & Masukan & Tindak lanjut \\
\hline \multirow[t]{3}{*}{$\begin{array}{l}\text { Ahli } \\
\text { Materi }\end{array}$} & $\begin{array}{l}\text { Susunan kata pada } \\
\text { hukum Ohm diperbaiki }\end{array}$ & $\begin{array}{l}\text { Mendahulukan } \\
\text { kata beda } \\
\text { potensial sebagai } \\
\text { penyebab } \\
\text { munculnya arus }\end{array}$ \\
\hline & $\begin{array}{l}\text { Persamaan hambatan } \\
\text { sesuai dengan } \\
\text { urutannya }\end{array}$ & $\begin{array}{l}\text { Mengurutkan } \\
\text { kembali } \\
\text { persamaan }\end{array}$ \\
\hline & $\begin{array}{l}\text { Konsistensi penulisan } \\
\text { hambatan atau resistor } \\
\text { dalam modul }\end{array}$ & $\begin{array}{l}\text { Merubah kata } \\
\text { resistor dengan } \\
\text { kata hambatan }\end{array}$ \\
\hline \multirow[t]{3}{*}{$\begin{array}{l}\text { Ahli } \\
\text { Media }\end{array}$} & $\begin{array}{l}\text { Judul pada kegiatan } \\
\text { siswa II hendaknya } \\
\text { diperbesar }\end{array}$ & $\begin{array}{l}\text { Judul sudah } \\
\text { diperbesar }\end{array}$ \\
\hline & $\begin{array}{l}\text { Warna pada modul } \\
\text { perlu diberi warna- } \\
\text { warna yang cerah }\end{array}$ & $\begin{array}{l}\text { Setiap kegiatan } \\
\text { telah dikombinasi } \\
\text { dengan beberapa } \\
\text { warna }\end{array}$ \\
\hline & $\begin{array}{l}\text { Penulisan persamaan } \\
\text { diperbesar }\end{array}$ & $\begin{array}{l}\text { Persamaan } \\
\text { diperbesar } \\
\text { tulisannya }\end{array}$ \\
\hline \multirow[t]{3}{*}{$\begin{array}{l}\text { Ahli } \\
\text { Bahasa }\end{array}$} & $\begin{array}{l}\text { Beberapa paragraf } \\
\text { belum menjorok }\end{array}$ & Sudah diperbaiki \\
\hline & $\begin{array}{l}\text { Penggunaan di- dan ke- } \\
\text { sebagai kata depan atau } \\
\text { sambung. }\end{array}$ & $\begin{array}{l}\text { Sudah ditinjau } \\
\text { ulang }\end{array}$ \\
\hline & $\begin{array}{l}\text { Penulisan kata asing } \\
\text { seperti “Current" hal.19 } \\
\text { dengan huruf miring }\end{array}$ & Sudah diperbaiki \\
\hline \multirow[t]{3}{*}{$\begin{array}{l}\text { Praktisi } \\
\text { pendidikan }\end{array}$} & $\begin{array}{l}\text { Penulisan yang } \\
\text { menunjukkan } \\
\text { keterangan gambar } \\
\text { menggunakan huruf } \\
\text { kapital pada kata } \\
\text { "Gambar 3.7" }\end{array}$ & Sudah diperbaiki \\
\hline & $\begin{array}{l}\text { Penulisan kata yang } \\
\text { kurang sesuai seperti } \\
\text { halaman } 16 \text { kata } \\
\text { "smakin", "yng" }\end{array}$ & $\begin{array}{l}\text { Sudah diperbaiki } \\
\text { penulisannya }\end{array}$ \\
\hline & $\begin{array}{l}\text { Penulisan titik koma } \\
\text { pada } \\
\text { diperhatikan }\end{array}$ & $\begin{array}{l}\text { Sudah ditinjau } \\
\text { ulang }\end{array}$ \\
\hline
\end{tabular}

Keseluruhan masukan dari para ahli dan praktisi pendidikan merupakan tidak lanjut dari revisi pembimbing. Saran/masukan yang diberikan dijadikan dasar untuk perbaikan modul. Selanjutnya, hasil revisi I ini dijadikan sebagai produk yang digunakan untuk uji coba terbatas di sekolah pada tahap implementasi.
Setelah draf awal modul direvisi dihasilkan draf modul I yang telah direvisi berdasarkan masukan para validator. Draf modul I selanjutnya diujicobakan kecil kepada 9 siswa di SMA PIRI 1. Hasil uji coba kecil berupa angket keterbacaan modul dan jawaban siswa pada LKS yang digunakan sebagai bahan untuk revisi produk.

Hasil analisis uji coba kecil menunjukkan terdapat beberapa bagian yang perlu direvisi. Siswa masih belum dapat menjawab sempurna dalam forum diskusi pada pertanyaan nomor 2 . Perbaikan kalimat pertanyaan dilakukan dengan mengganti kata "hipotesis" dengan kata "jawaban sementara". Siswa merumuskan masalah yang tidak sesuai dengan yang diharapkan pada Fenomena 1 seperti: "Sebutkan benda-benda yang menggunakan arus listrik?", sehingga dilakukan perbaikan kalimat pada wacana Fenomena 1. Hasil perbaikan hasil uji coba disajikan pada Tabel 4.

Tabel 4 Perbaikan Hasil Uji Coba Terbatas

\begin{tabular}{ll}
\hline \multicolumn{1}{c}{ Sebelum perbaikan } & \multicolumn{1}{c}{ Setelah perbaikan } \\
\hline Kegiatan pada forum diskusi & "Tuliskan jawaban \\
pada pertanyaan nomor 2 & sementara dari rumusan \\
bertuliskan: "Tuliskan hipotesis & masalah pada Fenomena 1 \\
dari rumusan masalah pada & dan tuliskan jawaban \\
fenomena 1!" & sementara tersebut pada \\
& tempat yang disediakan!" \\
\hline kalimat pada Fenomena 1: & Segala macam barang \\
Hampir segala macam benda & elektronik selalu \\
yang digunakan oleh manusia & membutuhkan arus listrik \\
sekarang ini menggunakan arus & untuk dapat bekerja. \\
listrik. & \\
\hline
\end{tabular}

Pendapat dari beberapa siswa dijadikan bahan untuk merevisi draf modul I menjadi draf modul II yang siap diuji coba luas. Hasil perbaikan berdasarkan uji coba kecil akan menjadi draf modul II yang siap digunakan untuk uji coba besar.

Setelah melewati rangkaian proses uji coba kecil serta revisi terhadap draf modul I dihasilkan draf modul II yang siap diimplementasikan pada siswa dalam skala luas. Uji coba luas dilakukan pada 20 siswa kelas XB SMA PIRI 1 Yogyakarta.

Implementasi modul ini dilakukan untuk melihat peningkatan kemampuan berpikir kritis siswa sebelum dan setelah diberikan pembelajaran menggunakan modul inkuiri terbimbing. Kelas yang digunakan untuk 
implementasi modul hanya satu kelas sehingga peningkatan kemampuan berpikir kritis dilihat dari nilai pretest dengan nilai posttest yang dianalisis menggunakan perhitungan $n$-gain. Hasil perhitungan $n$-gain sebesar 0,52 pada kriteria "sedang" serta dilihat berdasarkan KKM yang ditetapkan sekolahan yaitu $\geq 75$ yang ditunjukkan dengan nilai siswa diatas KKM.

\section{d. Penyebaran}

Tahap selanjutnya adalah penyebaran modul fisika SMA kelas $\mathrm{X}$ berbasis inkuiri terbimbing pada materi listrik dinamis. Modul disebarkan ke 4 guru fisika SMA di Kota Yogyakarta.

Tabel 5. Hasil Respon Guru Fisika

\begin{tabular}{ccc}
\hline Guru & Skor & Kategori \\
\hline 1 & 142 & Baik \\
2 & 144 & Sangat Baik \\
3 & 145 & Sangat Baik \\
4 & 145 & Sangat Baik \\
\hline Rerata & 144 & Sangat Baik \\
\hline
\end{tabular}

Berdasarkan Tabel 5 menunjukkan bahwa analisis hasil penyebaran didapatkan rata-rata skor yaitu 144 dari rentang skor 34 sampai 170 dan persentase keidealan $84,70 \%$ dengan kategori "sangat baik".

\section{Pembahasan Produk}

a. Pendefinisian

Analisis kebutuhan siswa menunjukkan bahwa siswa $85 \%$ siswa telah memiliki buku pegangan dengan judul dan sumber yang berbeda-beda. Buku pegangan siswa masih lebih banyak menyajikan informasi dan kurangnya latihan-latihan siswa yang melatih kemampuan berpikir kritis mengakibatkan siswa cepat lupa dengan materi yang disajikan. Oleh sebab itu, diperlukan modul yang sesuai dengan kebutuhan siswa dalam pembelajaran. Hal ini sesuai dengan pendapat Houston dan Howson dalam Wena (2009) yang menyatakan bahwa modul pembelajaran meliputi seperangkat aktivitas yang bertujuan mempermudah siswa untuk mencapai seperangkat tujuan pembelajaran.

Hasil angket kebutuhan guru menunjukkan $100 \%$ guru masih membutuhkan bahan ajar seperti modul berbasis inkuiri terbimbing untuk meningkatkan kemampun berpikir kritis siswa. Sejalan dengan pendapat Daryanto (2013) bahwa modul adalah suatu alat bantu yang digunakan oleh guru dalam membantu dan menemukan konsep yang dapat meningkatkan suatu keterampilan dan kemampuan yang dimiliki oleh siswa.

\section{b. Perancangan}

Modul disusun menjadi suatu bahan ajar yang tepat dengan karakteristik modul yang dikembangkan berdasarkan Depdiknas (2008) yaitu: 1) self instructional, 2) self contained, 3) stand alone, 4) adaptive, 5) user friendly. Melalui modul siswa dapat meningkatkan kemandirian dan keaktifan dalam belajar melalui instruksi serta paparan informasi yang sederhana, umum dalam kehidupan, dan mudah dimengerti.

Modul diintegrasikan dengan indikator berpikir kritis pada setiap langkahnya dan dilengkapi dengan ikon-ikon yang membantu siswa dalam setiap langkah-langkahnya yaitu: 1) langkah orientasi, siswa dilatih untuk mengasah kemampuan berpikir kritis dalam memahami fenomena terkait kehidupan seharihari dalam wacana yang disajikan, 2) langkah merumuskan masalah, siswa dilatih untuk mengidentifikasi masalah yang terdapat dalam fenomena; 3) langkah merumuskan hipotesis, tahap siswa dalam merumuskan hipotesis dari rumusan masalah yang dibuat; 4) langkah mengumpulkan data merupakan langkah yang melatih siswa melakukan pengumpulan data dengan merancang percobaan untuk membuktikan hipotesis yang telah dituliskan dalam LKS; 5) langkah menguji hipotesis merupakan langkah pembuktian hipotesis melalui eksperimen; dan 6) langkah merumuskan kesimpulan merupakan langkah siswa merepresentasikan hasil percobaan yang telah dilakukan.

Modul yang disusun membahas tentang materi listrik dinamis dengan indikatorindikator pembelajaran berdasarkan pada Standar Kompetensi (SK) dan Kompetensi Dasar (KD) pada Kurikulum 2006 (KTSP). Kegiatan siswa dalam modul dikelompokkan menjadi 3 kegiatan berdasarkan materi yaitu 
arus listrik dan hukum ohm, rangkaian hambatan, serta energi dan daya.

Modul fisika SMA/MA kelas X pada materi listrik dinamis merupakan suatu modul yang membahas mengenai permasalahan permasalahan yang berkaitan dengan arus listrik dan alat ukurnya, besaran-besaran listrik rangkaian tertutup, serta listrik AC dan DC dalam kehidupan. Pembahasan modul dilengkapi dengan beberapa contoh dan latihan soal dengan harapan siswa lebih memahami konsep listrik dinamis yang dipelajarinya.

\section{c. Pengembangan}

Analisis hasil validasi dilakukan dengan perhitungan cut off score untuk mengetahui kelayakan modul. Sesuai perhitungan tersebut menunjukkan bahwa nilai rata-rata penilaian lebih dari cut off score $(81,27>81,17)$, maka dapat disimpulkan modul layak digunakan.

Modul yang telah dinyatakan layak digunakan kemudian dilakukan uji terbatas kepada 9 siswa kelas XA secara acak. Siswa diminta memahami dan mengerjakan modul pada LKS yang disediakan untuk mengetahui keterbacaan modul. Kendala dan ketidaksesuaian jawaban siswa digunakan sebagai saran/masukan untuk perbaikan modul.

Hasil perhitungan nilai pretest dan postest berdasarkan perhitungnya $n$-gain menunjukkan adanya peningkatan hasil belajar sebelum diberi modul inkuiri terbimbing dan sesudah diberi modul inkuiri terbimbing dengan nilai $n$ gain 0,52 dalam kategori "sedang", sejalan dengan penelitian Wulandari (2013) menunjukkan bahwa hasil perhitungan $n$-gain pada hasil pretest dan posttest untuk mengetahui peningkatan kemampuan berpikir kritis sebesar 0,45 dalam kategori "sedang". Didukung pula dengan penelitian Schwarz (2009) menunjukkan bahwa data survei dari tahap pengenalan oleh guru terjadi penurunan pada akhir semester yang difokuskan pada aktivitas siswa (17 dari 24 atau $71 \%$ pada pretest dibandingkan dengan posttest sebesar 11 dari 24 siswa atau 46\%), dan terjadi peningkatan yang difokuskan pada perubahan konsep (1 dari 24 atau 4\% pada pretest dibandingkan dengan 9 dari 24 siswa atau 38\% pada posttest) dan difokuskan pada inkuiri terbimbing (9 dari 24 siswa atau 38\% pada pretest dibandingkan dengan posttest 14 dari 24 siswa atau 58\%).

Keefektifan modul juga dapat dilihat dari pencapaian KKM yang telah ditentukan yaitu $\geq 75$. Siswa dengan nilai lebih dari 75 atau sama dengan 75 dinyatakan telah tuntas dalam hasil belajar. Hasil postest menunjukkan hampir semua siswa telah lulus KKM, sehingga dapat dikatakan modul inkuiri terbimbing efektif dalam pembelajaran.

\section{d. Penyebaran}

Tahap selanjutnya adalah penyebaran modul fisika berbasis inkuiri terbimbing pada materi listrik dinamis. Modul fisika berbasis inkuiri terbimbing pada materi listrik dinamis disebarkan ke 5 guru fisika SMA di Kota Yogyakarta. Penyebaran dilakukan kepada SMA yang mempunyai karakteristik sama dengan sekolahan tempat penelitian. Guru fisika masing-masing sekolah diberikan angket untuk mengetahui respon terhadap modul fisika yang telah dikembangkan. Respon guruguru terhadap modul fisika berbasis inkuiri terbimbing dalam kategori "sangat baik" dari tampilan dan isi serta langkah-langkah pembelajaran modul yang sesuai dengan kebutuhan siswa dalam belajar. Hasil ini sejalan dengan penelitian Sugiyanto (2013) bahwa pada tahap ini mendapatkan respon yang sangat baik, materi dalam modul tersusun secara sistematis, runtut sehingga mudah dipahami dan gambar dapat memperjelas konsep.

\section{Kesimpulan dan Rekomendasi}

Kesimpulan yang diperoleh dari penelitian pengembangan ini adalah: 1) Karakteristik modul fisika SMA kelas X yaitu: self instructional, self contained, stand alone, adaptive, user friendly dengan menggunakan model 4-D meliputi define, design, develop, dan disseminate yang dikembangkan dengan berbasis inkuiri terbimbing pada materi listrik dinamis dan diintegrasikan dengan kemampuan berpikir kritis pada setiap tahapnya. 2) modul pembelajaran fisika berbasis inkuiri terbimbing pada materi listrik dinamis divalidasi oleh dosen, guru, dan praktisi pendidikan. Hasil validasi 
menunjukkan bahwa modul pembelajaran fisika berbasis inkuiri terbimbing pada materi listrik dinamis layak digunakan untuk meningkatkan kemampuan berpikir kritis siswa dilihat dari nilai rata-rata hasil validasi 81,27 lebih besar dari nila cut off yaitu 81,17 ; 3) modul fisika berbasis inkuiri terbimbing pada materi listrik dinamis dapat meningkatkan kemampuan berpikir kritis siswa ditunjukkan dengan nilai $n$-gain sebesar 0,52 dalam kategori "sedang" dan dilihat dari KKM siswa, hasil test menunjukkan hampir semua siswa memenuhi KKM.

Guru hendaknya mulai untuk mengembangkan atau menggunakan modul pembelajaran fisika yang melatih kemampuan berpikir tingkat tinggi di kelas agar sesuai dengan karakteristik siswa.

Hasil penelitian ini dapat digunakan sebagai acuan untuk mengembangkan penelitian sejenis. Peneliti dapat mengembangkan modul dengan karakteristik model pembelajaran dan materi yang berbeda.

\section{Daftar Pustaka}

Daryanto. (2013). Menyusun Modul (Bahan Ajar untuk Persiapan Guru dalam Mengajar). Yogyakarta: Gava Media.

Departemen Pendidikan Nasional Dirjen Manajemen Pendidikan Dasar dan Menengah Direktorat Pembinaan Sekolah Menengah Atas. (2008). Panduan Pengembangan Bahan Ajar, Jakarta: Depdiknas

Prastowo, A. (2014). Panduan Kreatif Membuat Bahan Ajar Inovatif. Yogyakarta: DIVA Press.

Santrock. (2008) Psikologi Pendidikan. Jakarta: Salemba Humanika.

Sugiyanto. (2013). Pengembangan Modul Berbasis Inkuiri Terbimbing Disertai Multimedia pada Materi Keanekaragaman Makhluk Hidup di SMPN 1 Kendal Kabupaten Ngawi. Surakarta: Universitas Sebelas Maret.

Suparno, P. (2013). Metodologi Pembelajaran Fisika. Konstruktivistik \& Menyenangkan. Yogyakarta: Universitas Sanata Darma.
Schwarz, C. (2009). Developing Preservice Elementary Teachers Knowledge and Practices Through Modeling-Centered Scientific Inquiry. Department of Teacher Education. USA: Michigan State University.

Wena, M. (2009). Strategi Pembelajaran Inovatif Kontemporer, Jakarta: Bumi Aksara.

White, B. Y. \& Shimoda, T. A.. (1999). Enabling Student to Construct Theories of Collaborative Inquiry and Revlective Learning Computer Support for Metakognitif Development. Internasional Journal of Artificial Intelligenci in Education, ((10): 151-182).

Winnie, S. (2009). Pendekatan Kombinasi Metode AHP dan Metode Cut Off Point pada Tahap Analisis Keputusan Perancangan Sistem Informasi Penjualan PT.X.http://eprints.undip.ac.id.

Wulandari, E. (2013). Pengembangan Modul Pembelajaran Berorientasi SETS pada Materi Listrik Dinamis untuk Meningkatkan Kemampuan Berpikir Kritis Siswa SMAN 1 Ngimbang Lamongan Jawa Timur. Surakarta: Universitas Sebelas Maret. 